DOI: https://doi.org/10.47405/mjssh.v5i7.448

\begin{tabular}{|c|c|}
\hline $\operatorname{los}_{15}$ & Malaysian Journal of Social Sciences and Humanities (MJSSH) \\
\hline Malaysian Journal of & Volume 5, Issue 7, July 2020 \\
\hline $\begin{array}{l}\text { Humantites } \\
\text { (MJ - SSH) }\end{array}$ & e-ISSN : 2504-8562 \\
\hline & $\begin{array}{l}\text { Journal home page: } \\
\text { www.msocialsciences.com }\end{array}$ \\
\hline
\end{tabular}

\title{
Domain dan Bahasa Pilihan Tiga Generasi Etnik Bajau Sama Kota Belud
}

\author{
Berawati Renddan', Adi Yasran Abdul Aziz', Hasnah Mohamad', Sharil Nizam Sha'ri' \\ 1Faculty of Modern Languages and Communication, Universiti Putra Malaysia (UPM)
}

Correspondence: Berawati Renddan (bera_wawa@yahoo.com)

\begin{abstract}
Abstrak
Etnik Bajau Sama merupakan etnik kedua terbesar di negeri Sabah. Kawasan petempatan utama etnik Bajau Sama di Sabah terletak di Kota Belud di Pantai Barat. Sebagai masyarakat yang dwibahasa, pilihan penggunaan bahasa masyarakat yang beragama Islam ini adalah berbeza-beza mengikut generasi dan domain yang berkemungkinan tidak berpihak kepada bahasa ibunda. Teori Analisis Domain (Fishman) diterapkan bagi mengkaji pilihan bahasa dalam domain khusus oleh peserta kajian dari Kampung Taun Gusi, Kota Belud, Sabah. Kaedah tinjauan dengan soal selidik digunakan untuk mendapatkan maklumat daripada generasi pertama (GI), kedua (GII) dan ketiga (GIII). Nilai min bagi setiap kumpulan dlam domain kekeluargaan menunjukkan bahawa GI dan GII Lebih banyak menggunakan bahasa Bajau Sama manakala GIII lebih cenderung kepada bahasa Melayu. Dalam domain kejiranan, GI memilih bahasa Bajau Sama namun GII dan GIII masing-masing memilih BM. Walau bagaimanapun, dalam domain pendidikan, keagamaan, perkhidmatan dan jual-beli, semua generasi memilih bahasa Melayu. Penemuan yang paling penting ialah generasi muda (GIII) kini sudah beralih kepada bahasa Melayu dalam domain kekeluargaan dan domain awam. Generasi ini bertindak sebagai pemangkin peralihan bahasa yang mendatangkan ancaman kepada daya hidup bahasa Bajau Sama, khususnya dalam domain tidak formal seperti kekeluargaan dan kejiranan. Dapatan ini menunjukkan adanya kemerosotan transmisi bahasa ibunda antara generasi dalam kalangan masyarakat etnik Bajau Sama.
\end{abstract}

Kata kunci: Bajau Sama, analisis domain, generasi penutur, bahasa Melayu, peralihan bahasa

\section{Domain and Language Choice by Three Generation of Kota Belud Sama Bajau Ethnic}

\begin{abstract}
The Bajau Sama is the second largest ethnic group in Sabah. The main ethnic settlement of Bajau Sama in Sabah is located at Kota Belud on the West Coast. As a bilingual community, the choice of language by this Muslim community varies according to generations and domains which may not favor the native language. The Domain Analysis Theory (Fishman) is applied to study the choice of language in a specific domain by participants from Kampung Taun Gusi, Kota Belud, Sabah. Survey methods with questionnaires were used to obtain information from the first (GI), second (GII) and third (GIII) generations. The mean value for each group in the family domain indicated that the GI and GII used more language Bajau Sama while the GIII tendency was towards Malay. In the neighborhood domain, GI has chosen Bajau Sama language but GII and GIII preferred BM. However, in education, religious services, and purchasing domains, all generations preferred Malay. The most important finding was the younger generation (GIII) has shifted to Malay in the family domain and in all public domains. This
\end{abstract}


DOI: https://doi.org/10.47405/mjssh.v5i7.448

generation acted as a catalyst for language shift which posed a threat to the Bajau Sama language vitality even in informal domains such as family and neighborhood. This finding shows there is a decline in the intergenerational language transmission of the mother tongue among the Bajau Ethnic communities.

Keywords: Bajau Sama, domain analysis, generation of speakers, Malay, language shift

\section{Pengenalan}

Etnik Bajau Sama merupakan etnik kedua terbesar di negeri Sabah. Etnik Bajau gemar menggunakan nama Sama atau A'asamah berbanding Bajau (Sather, 1974), iaitu nama panggilan daripada orang asing kepada mereka. Etnik Bajau Sama kebanyakannya penutur dwibahasa. Keluarga bahasa Bajau Sama mencatat bilangan penutur yang paling ramai selepas bahasa Dusun. Dalam penulisan penyelidik terdahulu seperti Sather, perkataan 'Sama' dieja 'Samah', namun dalam kajian ini penyelidik menggunakan perkataan 'Sama' berikutan pandangan golongan tua bangsa itu yang menetap di daerah Kota Belud. Mereka berpendapat kata nama khas 'Samah' bukan sebutan yang betul, yang lebih tepat ialah 'Sama'. Konsonan ' $h$ ' perlu digugurkan atas alasan etnik Bajau Sama tidak menyebut konsonan 'h' apabila menyebut perkataan 'Sama'.

Dua kawasan yang dikenal pasti menjadi petempatan utama etnik Bajau di Sabah ialah daerah Kota Belud di Pantai Barat dan Semporna di Pantai Timur (Saidatul, 2012). Dialek Bajau di Pantai Barat Sabah jauh berbeza dengan bahasa Sama yang dituturkan etnik yang sama di selatan Filipina dan di Pantai Timur Sabah. Bahasa Bajau Pantai Barat ialah satu entiti tersendiri dalam bahasa Bajau. Dalam bahasa ini, terdapa tiga subdialek; iaitu subdialek utama yang besar dan dituturkan oleh Bajau di sepanjang Pantai Barat Sabah, subdialek yang digunakan penduduk Bajau di daerah Pitas dan subdialek di daerah Sandakan.

Kota Belud merupakan sebuah daerah yang tertua dalam negeri Sabah. Kota Belud dibuka pada tahun 1901. Menurut Evan (1955), penempatan orang Bajau yang ditemui pada tahun 1901 di daerah Tempasuk (Kota Belud) memperlihatkan satu keadaan petempatan yang kukuh. Keadaan ini memungkinkan ramalan petempatan tersebut telah bertapak sekurang-kurangnya 200 tahun lampau. Daerah ini terletak di kawasan pantai barat Sabah yang meliputi kawasan seluas 1386 kilometer persegi kira-kira 77 kilometer dari Kota Kinabalu. Kebanyakan orang Bajau Sama ialah penutur dwibahasa yang menggunakan bahasa ibunda dan bahasa kebangsaan (Melayu). Banker (1984) melaporkan dalam kajiannya mengenai purata kesalinganfahaman penggunaan bahasa kebangsaan (bahasa Melayu) dalam kalangan Bajau Sama yang berpendidikan dan tidak berpendidikan adalah sebanyak $86 \%$. Bahasa Melayu berfungsi sebagai medium pengajaran, bersama bahasa Inggeris bagi pendidikan yang lebih tinggi dalam kerajaan dan sektor perniagaan.

\section{Pernyataan Masalah}

Masalah yang dikemukakan dalam tulisan ini ialah perilaku bahasa peserta kajian yang terdiri daripada etnik Bajau Sama. Bagi mengetahui perilaku bahasa tersebut teori yang diterapkan ialah teori analisis domain (Fishman, 1971) sebagai teori dasar. Salah satu faktor penentu dalam memilih bahasa ialah domain. Domain merupakan konteks situasi dalam kaitannya dengan lingkungan sosial tempat peristiwa tutur terjadi. Dalam teori analisis domain diandaikan bahawa terdapat lima domain yang berkaitan dengan kehidupan masyarakat, iaitu kekeluargaan (family domain), kejiranan atau persaudaraan (friendship domain), keagamaan (religion domain), pendidikan (education domain), dan pekerjaan (employment domain). Domain-domain tersebut merupakan faktor penting dalam penggunaan bahasa di samping faktor penutur, situasi, lokasi, dan waktu. Dalam sesuatu domain berlaku interaksi biasa antara peserta penutur dan pendengar perbualan berlatarkan situasi formal atau tidak formal (Holmes, 2001: 22). 
Kebanyakan generasi Bajau Sama ialah penutur dwibahasa. Oleh sebab itu, pemilihan penggunaan bahasa dalam sesuatu domain dapat berupa campur kod dan alih kod. Campur kod ialah penggunaan bahasa dengan mencampurkan kata-kata daripada bahasa lain ke dalam bahasa dasar. Kod-kod bahasa hanya serpihan dalam bahasa utama. Dengan kata lain, dalam situasi campur kod ada sebuah kod utama yang memiliki fungsi dan kemandiriannya, sedangkan kod lain dalam peristiwa tutur hanyalah pengisi tanpa fungsi sebagai kod utama. Alih kod terjadi apabila penggunaan variasi bahasa berpindah ke variasi bahasa lain jika situasi menghendaki (Sartini, 2015: 55). Hal yang membimbangkan penyelidik ialah apabila hanya satu bahasa (bahasa Melayu) digunakan dalam semua urusan kehidupan etnik Bajau Sama, manakala bahasa ibunda pula disishkan yang menyebabkan peralihan kepada bahasa Melayu. Berdasarkan kajian rintis yang telah dijalankan oleh penyelidik, didapati bahawa bahasa Bajau Sama semakin kurang berfungsi sebagai bahasa di rumah dalam kalangan generasi muda. Atas kesedaran inilah maka penyelidik berusaha untuk meneliti pilihan penggunaan bahasa dalam domain khusus oleh tiga generasi daripada etnik Bajau Sama.

\section{Persoalan Kajian}

Bahasa apakah yang sering digunakan oleh responden tiga generasi etnik Bajau Sama dalam domain khusus?

\section{Objektif Kajian}

Tujuan kajian ini dijalankan adalah untuk mengenal pasti pemilihan bahasa oleh tiga generasi penutur bahasa Bajau Sama dari Kampung Taun Gusi di Kota Belud, Sabah dalam domain kekeluargaan, kejiranan, pendidikan, keagamaan, dan jual beli. Faktor dwibahasa memungkinkan mereka memilih bahasa yang lebih dominan daripada bahasa Bajau Sama.

\section{Sorotan Literatur}

Domain penggunaan bahasa dan faktor makro sosial memainkan peranan sebagai pemangkin peralihan bahasa dalam sesebuah masyarakat. Hasil kajian ini diperoleh Ravindranath (2009) dalam kalangan komuniti Garifuna di Belize. Peralihan bahasa ialah proses dalam konteks penutur dwibahasa yang secara beransur-ansur berhenti menggunakan salah satu daripada dua bahasa dan penutur lebih memihak kepada bahasa dominan. Faktor-faktor penyebab peralihan bahasa secara amnya dianggap bersifat sosial. Ravindranath memberi perhatian kepada sikap penutur dan kesan peralihan bahasa dalam komuniti Garifuna di Belize. Dapatan kajiannya menunjukkan perubahan motivasi akibat pengaruh luar dan status sosiologi menyebabkan peralihan kepada bahasa yang dominan dalam masyarakat tersebut. Perilaku bahasa generasi penutur yang berumur 30-49 tahun menunjukkan peralihan bahasa terjadi disebabkan perubahan sikap dalam masyarakat yang lebih mengutamakan bahasa Inggeris dalam domain perkhidmatan.

Satu kajian tentang perubahan leksikal dailek Melayu Sarawak telah dijalankan oleh Zuraini (2014). Penyelidikan ini mencakupi usaha pengumpulan kata dialek Melayu Sarawak yang berubah mengikut empat generasi penutur dialek Melayu Sarawak, iaitu tua, dewasa, remaja, dan kanak-kanak di kawasan Demak Baru Fasa 1, 2 \& 3 dalam kawasan Petra Jaya, Kuching, Sarawak. Dapatan kajian menunjukkan generasi tua mempunyai pengetahuan leksikal asli dialek Melayu Sarawak sebanyak 56 peratus. Pengetahuan leksikal asli generasi dewasa adalah sebanyak 23 peratus, pengetahuan generasi remaja adalah sebanyak 20 peratus manakala pengetahuan dalam kalangan kanak-kanak hanya satu peratus. Data ini menunjukkan bahawa dialek Melayu Sarawak dilanda perubahan pada tingkat kedua tekanan bahasa, iaitu di pinggiran. Bahasa pada tingkat pinggiran masih hidup dan masih mempunyai jumlah penutur yang agak banyak tetapi bilangan penuturnya terus menurun. Sifat leksikon dialek Melayu Sarawak dari segi makna yang telah dikenal pasti oleh Zuraini (2014) ialah leksem (metafora dan idiom), kata kacukan, kata serapan, kata rujukan, kata adjektif dan kata tabu. Kajian ke atas 
aplikasi teori Stratum Bawah menunjukkan pengurangan peratusan sampel yang memilih dialek Melayu Sarawak sebagai bahasa pertama daripada 15 peratus kepada 3 peratus manakala peratusan bahasa Melayu baku meningkat daripada 3 peratus kepada 9 peratus. Penggunaan dialek Melayu Sarawak sebagai bahasa ibunda dalam kalangan generasi dewasa lebih tinggi daripada generasi tua, diikuti oleh remaja dan tercorot ialah kanak-kanak. Hal ini demikian kerana generasi tua pada suatu ketika dalam hidup mereka terpaksa menerima pengaruh bahasa pemerintah demi keselamatan dan kelangsungan hidup.

Kajian yang dijalankan oleh Sartini (2015) menerangkan penggunaan bahasa Bali di Jawa Timur dalam beberapa domain. Pemerhatian dibuat dalam domain keluarga, adat, pendidikan, dan persahabatan. Analisis menunjukkan bahawa dalam domain kekeluargaan terdapat tiga bahasa yang digunakan iaitu bahasa Bali, Jawa, dan Indonesia. Ketiga-tiga bahasa itu boleh bertukar ganti dalam komunikasi. Dalam domain keagamaan, bahasa Bali masih dipelihara ketika melakukan upacara ritual. Dalam domain persahabatan terdapat pencampuran kod bahasa Bali, Jawa dan Indonesia. Dalam domain pendidikan, terutama dalam proses pengajaran dan pembelajaran pendidikan agama, bahasa yang digunakan ialah bahasa Indonesia.

Pelaksanaan kajian tinjauan oleh Reduan (2015) adalah bertujuan untuk mengenal pasti antara lain ialah lingkungan domain penggunaan bahasa masyarakat Melayu Saribas di Sarawak. Penyelidikan ini menghasilkan beberapa penemuan yang penting dalam konteks masyarakat Melayu Saribas. Dalam domain situasi formal (pejabat, klinik, sekolah dan masjid) bahasa Melayu standard digunakan secara berselang-seli dengan dialek Melayu Saribas tetapi dialek Melayu Saribas masih digunakan dengan meluas oleh sampel kajian daripada semua generasi. Dalam domain tidak formal, kod bahasa yang digunakan tidak bergantung pada generasi penutur. Sebaliknya, kod perbualan lebih bergantung pada domain, bukan pada generasi penutur. Sebagai kesimpulan, dalam domain formal bahasa yang digunakan ialah bahasa Melayu standard. Kod bahasa dalam domain tidak formal ialah dialek Melayu Saribas. Dalam kedua-dua domain tersebut lazim berlaku alih kod metaforikal.

Sarri (2016) mengkaji generasi kedua individu dwibahasa keturunan Albania yang berhijrah ke Greece. Tujuan kajian ini adalah untuk mengenal pasti corak komunikasi peserta di persekitaran rumah dan sekolah, menyelidiki insentif, rasional, dan syarat-syarat komunikasi serta sikap peserta terhadap bahasa Albania. Keputusan menunjukkan bahawa transmisi bahasa pertama bermasalah bagi kumpulan dwibahasa. Para peserta yang dilahirkan atau berhijrah ke Greece pada zaman kanak-kanak tidak menganggap bahasa ibunda mereka sebagai bahasa pertama yang diperoleh daripada keluarga. Konteks rumah merupakan satu-satunya domain di mana bahasa Albania digunakan dalam corak komunikasi yang tidak tetap. Penemuan juga menunjukkan tanda-tanda peralihan bahasa dalam kalangan generasi muda walaupun mereka mengatakan bahasa Albania masih digunakan sebagai simbol amalan ritual.

Objektif kajian Hotma (2017) adalah untuk mengenali faktor-faktor peralihan dalam kalangan orang Batak Toba di Pontianak. Penyusutan pemakaian bahasa Batak Toba di Bandar Pontianak bermula daripada GI. Para pendatang dalam kalangan penutur asli dari kampung halaman tidak mengekalkan pemakaian bahasa Batak Toba sepenuhnya dalam domain yang menunjukkan jati diri komuniti Batak Toba, iaitu dalam domain kekeluargaan, agama dan adat. Orang tua (ibu bapa) tidak berdaya mempertahankan bahasa Batak Toba semasa perbualan dengan anak dan cucu. Keadaan ini ditambah dengan tersedianya layanan ibadah dalam bahasa Indonesia oleh gereja kesukuan yang memiliki majoriti jemaah daripada komuniti Batak Toba. Bahasa menghilang bila tampak ada peralihan terhadap bahasa lain dalam masyarakat tempat bahasa dituturkan. Akibatnya pewarisan antara generasi berkurang, jumlah penutur utama menyusut, pemakaian yang sangat terhad dalam set domain, dan bahasa komunikasi yang lebih luas mulai menggantikan peranan bahasa ibunda di rumah atau keluarga. Bahasa Indonesia digunakan dalam semua domain perilaku bahasa oleh semua generasi komuniti Batak Toba di Bandar Puntianak. Bahasa Indonesia menjadi sangat berjaya di dalam kehidupan komuniti Batak Toba di bandar itu. Faktor keluarga (kesibukan ibu bapa), jiran, jual beli, pendidikan, pekerjaan, persahabatan dengan warga tempatan, pemerintahan, agama dan istiadat yang mulai longgar turut memperkukuhkan pengekalan bahasa Indonesia sebagai bahasa perhubungan dalam komuniti tersebut. 
Kajian yang dijalankan oleh Khairul (2017) bertujuan untuk mengenal pasti sikap dan motivasi yang dimiliki oleh murid-murid Bajau sekolah rendah di kawasan pedalaman. Mereka mempelajari bahasa Melayu sebagai bahasa kedua. Kajian ini juga bertujuan untuk mengenal pasti perbezaan gender dalam mempelajari bahasa Melayu. Dapatan kajian menunjukkan murid-murid Bajau sekolah rendah mempunyai sikap yang positif dan motivasi yang tinggi dalam mempelajari bahasa Melayu sebagai bahasa kedua. Hasil dapatan kajian juga menunjukkan terdapat perbezaan sikap dan motivasi antara murid lelaki dengan murid perempuan dalam mempelajari bahasa Melayu. Kesimpulannya, muridmurid Bajau menunjukkan sikap yang positif serta motivasi yang tinggi dalam mempelajari bahasa Melayu sebagai bahasa kedua.

\section{Teori Analisis Domain}

Fishman (1968: 17) mencadangkan bahawa ada konteks institusi tertentu, yang dipanggil 'domain', di mana satu bahasa atau pelbagai bahasa lebih sesuai daripada yang lain. Fishman mendefinisikan 'domain' sebagai 'konstruk sosio-budaya yang disari daripada topik-topik komunikasi, hubungan antara peserta komunikasi, dan lokasi komunikasi sesuai dengan institusi-institusi masyarakat dan lingkungan aktiviti pertuturan'. Dalam erti kata lain, domain dianggap sebagai sekelompok faktor, iaitu topik, hubungan antara peserta komunikasi dan lokasi komunikasi. Topik boleh menjadi pengawal selia penggunaan bahasa dalam tetapan penutur multibahasa. Sebagai contoh: seseorang menukar bahasa kepada bahasa pengantar semasa membincangkan topik tertentu. Hubungan antara peserta komunikasi bermakna bahawa bahasa yang digunakan ditentukan oleh peserta komunikasi yang bercakap dengan anda. Sebagai contoh: bapa bercakap kepada ibu, anak bercakap kepada ibu, dan ibu bercakap kepada anak. Fishman juga menyatakan bahawa lokasi komunikasi bermaksud tempat-tempat di mana perbualan berlaku mempengaruhi bahasa yang anda gunakan (Fishman, 1972: 20).

Menurut Fishman (1972: 55) lagi, domain adalah berkaitan dengan aktiviti komunikasi masyarakat dwibahasa atau multibahasa. Domain adalah seperti institusi-institusi sosial yang terdapat dalam masyarakat bahasa. Faktor utama yang menentukan domain ialah bidang umum (misalnya, agama, keluarga, pekerjaan), hubungan peranan antara para peserta komunikasi (misalnya, ibu-anak perempuan, ketua-setiausaha) dan latar interaksi berlaku (misalnya rumah ibadat, rumah, pejabat). Analisis pola pertuturan masyarakat dwibahasa atau multibahasa melibatkan kod dalam dua latar, iaitu latar formal dan latar tidak formal. Latar formal seperti di pejabat dikenali sebagai perbualan variasi tinggi (high variety). Latar tidak formal seperti di rumah dikenali sebagai perbualan variasi rendah (low variety). Situasi sosial yang umum dan perilaku pertuturan semasa penutur memilih satu bahasa atau kod daripada yang lain juga diberi istilah 'domain'. Sebagai contoh, di majlis makan malam keluarga, biasanya menggunakan ragam rendah. Di pejabat dan sekolah penutur menggunakan ragam tinggi. Menurut Fishman lagi, analisis domain menerangkan penggunaan bahasa dalam pelbagai konteks institusi masyarakat. Terdapat kecenderungan satu bahasa lebih sesuai dalam beberapa konteks tertentu daripada yang lain. Dari perspektif sosial, satu bahasa lebih sesuai daripada yang lain dalam domain tertentu kerana faktor seperti topik, hubungan antara peserta komunikasi dan lokasi komunikasi. Biasanya bahasa standard atau bahasa berprestij digunakan dalam domain tinggi, manakala bahasa vernakular (bahasa yang dituturkan oleh golongan atau kaum tertentu) dipilih dalam domain yang rendah.

\section{Metod Kajian}

Kaedah tinjauan digunakan oleh penyelidik untuk memperoleh maklumat tentang bahasa pilihan dalam domain khusus oleh peserta kajian di lapangan. Lokasi kajian dalam penyelidikan ini tertumpu di kampung Taun Gusi, Kota Belud, Sabah. Sebab utama pemilihan lokasi kajian ialah kawasan ini didiami oleh majoriti etnik Bajau Sama. Seramai 60 peserta kajian daripada etnik Bajau Sama yang terdiri daripada tiga generasi penutur terlibat dalam kajian ini. Mereka dipilih berdasarkan kaedah pensampelan rawak mudah. Jumlah peserta kajian bagi setiap generasi adalah sebanyak 20 orang. Generasi lanjut usia (GI) berumur dalam lingkungan 40-69 tahun. Generasi dewasa (GII) berumur antara 20-39 tahun. Generasi muda berumur 12 tahun ke bawah. Pembahagian ini bertujuan untuk 
membezakan pemilihan bahasa bagi generasi dari kumpulan yang berbeza-beza. Pengelompokan peserta kajian bersesuaian dengan konsep generasi pengguna bahasa dalam domain khusus yang dikemukakan oleh David (2002).

Soal selidik berstruktur yang diadaptasi daripada Hotma (2017: 330-333) dimanfaatkan bagi mendapatkan respons daripada tiga generasi penutur bahasa Bajau Sama. Soal selidik tersebut mengandungi item-item mengenai domain kekeluargaan (10 item), domain kejiranan (4 item), domain pendidikan (8 item), domain keagamaan (5 item) dan domain jual beli (4 item). Secara kuantitatif, penyelidik menggunakan IBM SPSS Statistics 23 untuk menganalisis jumlah, min dan sisihan piawai semua item soal selidik tentang 5 domain pilihan penggunaan bahasa penutur GI, GII dan GIII. Huraian kualitatif adalah berhubung dengan dapatan yang paling dominan bagi setiap pernyataan item soal selidik meliputi 5 domain tersebut. Hanya jumlah dan peratus pilihan penggunaan bahasa tertinggi, sama ada bahasa Bajau Sama (BBS), banyak bahasa Bajau Sama (BBBS), campuran Bahasa Bajau Sama dan bahasa Melayu (BBS+BM), banyak bahasa Melayu (BBM) atau bahasa Melayu (BM) dihuraikan secara tuntas.

\section{Dapatan Kajian}

Berdasarkan dapatan kajian yang diperoleh, analisis dan perbincangan terhadap pemilihan bahasa etnik Bajau Sama dilihat melalui beberapa domain. Domain yang diberi perhatian ialah kekeluargaan, kejiranan, pendidikan, keagamaan, perkhidmatan dan jual beli. Pemilihan bahasa dalam domain kekeluargaan adalah berdasarkan konteks santai di rumah etnik Bajau Sama semasa bersama anggota keluarga seperti orang tua dan adik-beradik.

\section{Domain Kekeluargaan}

Jadual 1 memaparkan pemilihan bahasa dalam domain kekeluargaan oleh tiga generasi etnik Bajau Sama di daerah Kota Belud, Sabah. G1 ialah peserta kajian yang berumur dalam lingkungan 40-69 tahun. GII ialah mereka yang berumur antara 20-39 tahun. GIII ialah generasi muda yang berumur 12 tahun ke bawah. Dalam domain kekeluargaan, bahasa Bajau Sama (BBS) paling banyak digunakan oleh GI. Jumlah pemilihan BBS dalam kalangan GI adalah sebanyak 84. Peserta kajian GII turut memilih BBS berbanding bahasa-bahasa lain namun jumlahnya kurang daripada GI, iaitu hanya sebanyak 62. Perbezaan jumlah respons terhadap BBS tampak ketara antara kedua-dua generasi ini kerana nilai min GI sebanyak 8.40 lebih tinggi daripada min 6.20 yang diperoleh GII meskipun serakan sisihan piawai (SD) dalam lengkung taburan normal hampir sama. Generasi lanjut usia (GI) masih mempertahankan status bahasa Bajau Sama sebagai citra leluhur masyarakat Bajau Sama di rumah. Dalam kalangan peserta GIII yakni generasi muda dilihat bahawa mereka cenderung menggunakan bahasa Melayu sebanyak 61 respons.

Jadual 1: Domain kekeluargaan

\begin{tabular}{ccccccc}
\hline Bil & G & & \multicolumn{5}{c}{ Pemilihan Bahasa } \\
\hline 1. & GI & BBS & BBBS & BBS+BM & BBM & BM \\
& Jum & 84 & 36 & 26 & 22 & 32 \\
& Min & 8.40 & 3.60 & 2.60 & 2.20 & 3.20 \\
& SD & 5.23 & 2.27 & 1.35 & 1.75 & 5.26 \\
2. & GII & & & & & \\
& Jum & 62 & 26 & 26 & 50 & 22 \\
& Min & 6.20 & 2.60 & 2.60 & 5.00 & 2.20 \\
& SD & 5.11 & 1.64 & 1.89 & 2.70 & 4.36 \\
3. & GIII & & & & & \\
& Jum & 4 & 4 & 14 & 53 & 61 \\
& Min & .40 & .40 & 1.40 & 5.30 & 6.10 \\
& SD & .84 & .84 & 1.89 & 4.42 & 5.17 \\
\hline
\end{tabular}


Data daripada soal selidik menunjukkan GI lebih banyak menggunakan Bahasa Bajau Sama dalam domain keluarga. Item yang paling kerap dipilih ialah 'Berbual dengan nenek/ datuk' (80\%). Mereka banyak menggunakan bahasa Bajau Sama sewaktu 'Berbual dengan suami/ isteri (30\%), banyak menggunakan bahasa Melayu apabila 'Berbual dengan anak kandung' (50\%). Bagi item 'Berbual dengan pembantu rumah' mereka memilih BM (70\%). GII paling kerap menggunakan bahasa Bajau Sama apabila 'Berbual dengan adik-beradik' (60\%). Namun mereka banyak menggunakan bahasa Melayu semasa 'Berbual dengan anak kandung' (50\%) dan lebih berminat 'Berbual dengan pembantu rumah' menggunakan BM (70\%). GIII menggunakan banyak bahasa Melayu dalam satu item iaitu 'Berbual tentang masalah seharian dengan anggota keluarga' (70\%).

\section{Domain Kejiranan}

Selain etnik Bajau Sama yang mendiami Kampung Taun Gusi, terdapat juga suku kaum lain yang ada di kampung ini seperti Iranun, Dusun, Kagayan, dan Melayu. Kehadiran suku kaum yang berbeza-beza ini mempengaruhi pilihan bahasa etnik Bajau Sama jika berhadapan dengan jiran yang berlainan etnik. Data kuantitatif dalam Jadual 2 menunjukkan hanya generasi lanjut usia (GI) memilih menggunakan bahasa Bajau Sama (BBS) semasa bersama-sama dengan jiran tetangga. Jumlah dalam kalangan GI yang memilih BBS adalah sebanyak 40. Generasi dewasa (GII) dan generasi muda (GIII) masingmasing memilih BM. Terdapat respons penggunan BM yang paling tinggi berjumlah 68 dengan min 17.00 dalam kalangan GIII jika dibandingkan dengan 25 respons daripada generasi dewasa GII.

Jadual 2: Domain Kejiranan

\begin{tabular}{ccccccc}
\hline Bil & G & \multicolumn{5}{c}{ Pemilihan Bahasa } \\
\hline 1. & GI & BBS & BBBS & BBS+BM & BBM & BM \\
& Jum & 40 & 11 & 10 & 5 & 14 \\
& Min & 10.00 & 2.75 & 2.50 & 1.25 & 3.50 \\
& SD & 8.28 & 3.09 & 3.78 & 1.50 & 7.00 \\
2. & GII & & & & & \\
& Jum & 22 & 6 & 9 & 18 & 25 \\
& Min & 5.50 & 1.50 & 2.25 & 4.50 & 6.25 \\
& SD & 9.71 & 1.29 & 1.70 & 3.69 & 5.37 \\
3. & GIII & & & & & \\
& Jum & 0 & 0 & 4 & 8 & 68 \\
& Min & .00 & .00 & 1.00 & 2.00 & 17.00 \\
& SD & .00 & .00 & 2.00 & 1.41 & 2.94 \\
\hline
\end{tabular}

Pemilihan bahasa GI dan GII terhadap bahasa Bajau Sama berdasarkan respons soal selidik memihak kepada item 'Jiran yang sama bangsa' (100\%). Dalam domain kejiranan, generasi muda menggunakan sama ada campuran bahasa Bajau Sama dan bahasa Melayu atau banyak bahasa Melayu. Akan tetapi GIII cenderung menggunakan BM dan memberi respons tertinggi bagi item 'Memberi nasihat kepada anak jiran' $(100 \%)$.

\section{Domain Pendidikan}

Dari segi susunan, respons GIII adalah sebanyak 157, GII (143 respons) dan GI (134 respons). Meskipun min bagi setiap generasi tidak jauh berbeza, nilai sisihan piawai 3.22 dalam data GII menunjukkan bukti bahawa respons daripada 20 generasi dewasa Bajau Sama kebanyakannya adalah sama. Dengan merujuk kepada respons soal selidik, penyelidik mengetahui bahawa semua generasi sama ada GI, GII mahupun GIII hanya memilih penggunan bahasa Melayu dalam domain pendidikan. Berdasarkan jumlah kekerapan, hanya satu item yang melibatkan GI, iaitu 'Bercakap dengan guru yang berasal dari negeri lain' (100\%). Respons tertinggi sebanyak seratus-peratus juga diperoleh daripada GII dan GIII bagi item 'Menjawab soalan guru', 'Bertanya kepada guru', 'Membuat pembentangan', 'Bercakap dengan guru dalam kelas', 'Bercakap dengan guru yang berasal dari negeri lain', dan 
'Bercakap semasa belajar di kelas'.

Jadual 3: Domain pendidikan

\begin{tabular}{ccccccc}
\hline Bil & G & \multicolumn{5}{c}{ Pemilihan Bahasa } \\
\hline 1. & GI & BBS & BBBS & BBS+BM & BBM & BM \\
& Jum & 0 & 3 & 7 & 15 & 134 \\
& Min & .00 & .38 & .88 & 1.88 & 16.75 \\
& SD & .00 & .74 & 1.12 & 1.12 & 2.05 \\
2. & GII & & & & & \\
& Jum & 0 & 0 & 2 & 15 & 143 \\
& Min & .00 & .00 & .25 & 1.88 & 17.88 \\
& SD & .00 & .00 & .707 & 2.94 & 3.22 \\
3. & GIII & & & & & \\
& Jum & 0 & 0 & 3 & 0 & 157 \\
& Min & .00 & .00 & .38 & .00 & 19.63 \\
& SD & .00 & .00 & .74 & .00 & .74 \\
\hline
\end{tabular}

\section{Domain Keagamaan}

Jadual 4 menunjukkan pemilihan bahasa oleh peserta kajian mengikut respons tertinggi. Generasi muda atau GIII memilih penggunaan BM sebanyak 83 respons diperkukuhkan min 16.60 yang lebih tinggi daripada dua generasi lain. Kedua tinggi diperoleh daripada data GII sebanyak 44 respons dan akhir sekali ialah GI (38 respons).

Jadual 4: Domain Keagamaan

\begin{tabular}{ccccccc}
\hline Bil & G & \multicolumn{5}{c}{ Pemilihan Bahasa } \\
\hline 1. & GI & BBS & BBBS & BBS+BM & BBM & BM \\
& Jum & 8 & 3 & 35 & 16 & 38 \\
& Min & 1.60 & .60 & 7.00 & 3.20 & 7.60 \\
& SD & 1.14 & 1.34 & 5.33 & 2.16 & 4.03 \\
2. & GII & & & & & \\
& Jum & 6 & 3 & 21 & 26 & 44 \\
& Min & 1.20 & .60 & 4.20 & 5.20 & 8.80 \\
& SD & 1.78 & .89 & 2.28 & 3.27 & 2.77 \\
3. & GIII & & & & & \\
& Jum & 0 & 0 & 0 & 17 & 83 \\
& Min & .00 & .00 & .00 & 3.40 & 16.60 \\
& SD & .00 & .00 & .00 & 4.77 & 4.77 \\
\hline
\end{tabular}

Secara huraian GI lebih banyak menggunakan bahasa Melayu daripada bahasa Bajau Sama, khususnya bagi item 'Berdoa' (65\%). GII lebih banyak menggunakan bahasa Melayu berbanding dengan bahasa Bajau Sama. Respons tertinggi diperoleh daripada item 'Belajar ajaran agama' (65\%). GIII memilih bahasa Melayu sepenuhnya dalam semua item soal selidik tetapi kadar peratus tertinggi diperoleh daripada item 'Berdoa' (100\%), 'Belajar ajaran agama' (100\%) dan 'Berbual dengan Jemaah di tempat ibadat' (100\%). Tiada seorang pun peserta GIII yang menggunakan bahasa Bajau Sama dalam domain keagamaan.

\section{Domain Perkhidmatan}

Pemilihan bahasa dalam Jadual 5 memperlihatkan semua generasi memberi respons tertinggi hanya 
DOI: https://doi.org/10.47405/mjssh.v5i7.448

pada penggunaan bahasa Melayu dengan susunan GIII (70 respons) dan GI juga GII masing-masing 34 respons. Hal ini disebabkan fungsi bahasa Melayu sebagai bahasa dominan dalam bidang perkhidmatan. Data daripada soal selidik menunjukkan GI dan GII hanya menggunakan bahasa Bajau Sama pada item 'Bertutur dengan ketua kampung' (100\%). GIII menggunakan bahasa Melayu pada kadar $100 \%$ ketika 'Bertutur tentang masalah kesihatan dengan doktor', 'Bertutur dengan pegawai di Pejabat Daerah, JPN, JPJ' dan 'Bertutur dengan agensi pelancongan dan perhotelan'.

Jadual 5: Domain perkhidmatan

\begin{tabular}{ccccccc}
\hline Bil & G & \multicolumn{5}{c}{ Pemilihan Bahasa } \\
\hline 1. & GI & BBS & BBBS & BBS+BM & BBM & BM \\
& Jum & 26 & 0 & 17 & 3 & 34 \\
& Min & 6.50 & .00 & 4.25 & .75 & 8.50 \\
& SD & 9.14 & .00 & 3.30 & .95 & 6.24 \\
2. & GII & & & & & \\
& Jum & 19 & 2 & 14 & 11 & 34 \\
& Min & 4.75 & .50 & 3.50 & 2.75 & 8.50 \\
& SD & 9.50 & 1.00 & 3.69 & 1.50 & 6.95 \\
3. & GIII & & & & & \\
& Jum & 3 & 0 & 5 & 2 & 70 \\
& Min & .75 & .00 & 1.25 & .50 & 17.50 \\
& SD & 1.50 & .00 & 2.50 & 1.00 & 5.00 \\
\hline
\end{tabular}

\section{Domain Jual-Beli}

Jadual 6 ialah perincian pemilihan bahasa semua peserta kajian mengikut generasi. Semua responden GI, GII dan GIII memilih bahasa Melayu dalam domain jual-beli. Jumlah respons daripada GI dan GII adalah sama, iaitu 41 dengan min 10.25. Jumlah respons tertinggi sebanyak 66 didapati daripada generasi muda dengan min 16.50. Dari segi taburan pemilihan item-item penggunaan bahasa dalam domain jual-beli, respons GIII tersebar lebih luas dengan sisihan piawai 3.69. Sehubungan itu, itemitem soal selidik yang signifikan ialah 'Meminta penjelasan penggunan barang elektronik di kedai' (100\%), 'Bertanya tentang kualiti barangan' (95\%), 'Bertanya harga barang di kedai' $(75 \%)$ dan ' Memesan barangan/ makanan’ (60\%).

Jadual 6: Domain jual-beli

\begin{tabular}{ccccccc}
\hline Bil & G & & & Pemilihan Bahasa & \\
\hline 1. & GI & BBS & BBBS & BBS+BM & BBM & BM \\
& Jum & 18 & 7 & 14 & 0 & 41 \\
& Min & 4.50 & 1.75 & 3.50 & .00 & 10.25 \\
& SD & .57 & 1.70 & .57 & .00 & .95 \\
2. & GII & & & & & \\
& Jum & 1 & 1 & 28 & 19 & 41 \\
& Min & .25 & .25 & 7.00 & 4.75 & 10.25 \\
& SD & .50 & .50 & 1.41 & 4.11 & 2.36 \\
3. & GIII & & & & & \\
& Jum & 0 & 0 & 12 & 2 & 66 \\
& Min & .00 & .00 & 3.00 & .50 & 16.50 \\
& SD & .00 & .00 & 3.83 & .57 & 3.69 \\
\hline
\end{tabular}




\section{Perbincangan}

Pilihan penggunaan bahasa ibunda dalam kalangan generasi lanjut usia menandakan kelompok ini ialah penutur jati. Mereka menggunakan bahasa ibunda sepenuhnya untuk berkomunikasi sama ada di dalam mahupun di luar rumah. Generasi ini tidak berpeluang mendapat pendidikan formal namun dalam kalangan mereka ada yang faham dan boleh bertutur bahasa Melayu (Zuraini, 2014 : 141). Hasil kajian ini menyokong pernyataan Noor Aina \& Syeril (2016: 46) bahawa generasi muda peribumi Sabah tidak kerap menggunakan bahasa ibunda sewaktu berkomunikasi dengan ahli-ahli keluarga. Kecenderungan generasi muda memilih bahasa Melayu (BM) sebagai bahasa komunikasi seharian dalam konteks santai di rumah telah menghakis status bahasa ibunda sebagai bahasa pertama. Kecenderungan tersebut adalah disebabkan kombinasi antara pergaulan dengan komuniti multibahasa dan bahasa perhubungan yang dominan dalam masyarakat (Mohammed Azlan, 2010: 101).

Bahasa Melayu telah dipilih sebagai bahasa pengantar dalam sistem pelajaran negara. Matlamat Dasar Pelajaran Kebangsaan menjelaskan dalam pendahuluan Akta pelajaran 1961 untuk menyatupadukan kanak-kanak sekolah berbilang etnik. Hal ini ditegaskan lagi dalam Laporan Razak 1956. Sejak itu, matlamat pelajaran menekankan perpaduan pelajar daripada pelbagai etnik (Jeniri 2013: 6). Sebagai bahasa ilmu, bahasa Melayu sesuai digunakan untuk mengungkapkan pelbagai disiplin ilmu. Justeru, masyarakat Bajau Sama daripada semua generasi dalam kajian ini memilih bahasa Melayu dalam domain pendidikan. Menurut hasil kajian Khairul (2017), kecenderungan memilih bahasa Melayu dalam domain pendidikan adalah disebabkan sikap yang positif dan motivasi yang tinggi dalam mempelajari bahasa Melayu sebagai bahasa kedua. Pemilihan bahasa dalam domain pendidikan ini banyak dipengaruhi oleh tahap pendidikan responden. Selain itu, etnik Bajau Sama beragama Islam dan mengamalkan budaya hidup orang Melayu. Fungsi tempat ibadat seperti masjid di Kampung Taun Gusi adalah berkaitan dengan solat, belajar agama, musyawarah dan aktiviti keagamaan lain. Penemuan ini menyokong kajian Hotma (2017) bahawa penyusutan pemakaian bahasa ibunda sudah dimulai daripada GI. Dalam kes bahasa Bajau Sama yang masyarakatnya beragama Islam, bahasa Arab amat sinonim dengan ibadah seharian malahan syariat dan ceramah-ceramah keagamaan disampaikan dalam bahasa Melayu.

Daerah Kota Belud di Sabah mempunyai banyak sumber ekonomi. Kebanyakan urusan ekonomi di sini ialah perniagaan. Terdapat bermacam-macam cara masyarakat Bajau Sama melaksanakan transaksi jual beli dalam urusan seharian. Penjaja berniaga di tepi jalan raya, warung makanan, pasar rakyat (gabungan berbagai-bagai pekedai yang diurus kerajaan tempatan) juga pasaraya yang menjual barangbarang keperluan harian. Dalam hal ini kod bahasa yang digunakan tidak bergantung pada generasi penutur. Sebaliknya, kod perbualan lebih bergantung pada domain, bukan pada generasi penutur (Reduan, 2015).

\section{Implikasi}

Penemuan yang paling penting daripada kajian ini ialah generasi muda telah beralih memilih bahasa Melayu dalam domain kekeluargaan dan domain-domain lain yang dikaji. Penemuan ini juga bermakna bahasa Melayu ialah bahasa dominan yang telah meresap dalam domain penggunaan bahasa di rumah. Apabila penyelidik merujuk skala pemeringkatan bahasa terncam oleh Fishman (1991), bahasa Bajau Sama di Kota Belud kini berada pada gred 3: Bahasa ini tidak lagi dipelajari sebagai bahasa ibunda oleh kanak-kanak di rumah. Penutur termuda ialah generasi ibu bapa. Pada peringkat ini, ibu bapa masih boleh bertutur dalam bahasa ibunda sewaktu bercakap dengan anak-anak mereka, tetapi anak-anak mereka biasanya tidak memberi respons dalam bahasa itu. Selain itu, sudah ada campur kod dan alih kod dalam komunikasi generasi muda etnik Bajau Sama di daerah Kota Belud. Pemilihan bahasa oleh penutur dalam kalangan generasi muda mudah berubah disesuaikan dengan domain tertentu.

Sebagai penutur dwibahasa, ahli masyarakat Bajau Sama di Kota Belud mempunyai pilihan sama ada menggunakan bahasa ibunda atau bahasa Melayu atau bahasa campuran dalam perbualan sehari-hari. Secara tidak langsung pemilihan bahasa sedemikian menentukan bahasa Bajau Sama terus kekal 
sebagai bahasa pertama atau beralih dengan cepat kepada bahasa Melayu yang lebih dominan. Hakikat ini lantaran bahasa Melayu ialah subjek wajib lulus di sekolah dan syarat ke institusi yang lebih tinggi. Motivasi instrumental sedemikian mempengaruhi persepsi ibu bapa dalam pilihan bahasa yang perlu bagi anak-anak mereka. Keperluan bahasa khususnya dalam tenaga kerja mendorong ibu bapa memilih pendedahan bahasa yang sesuai dengan kejayaan dan kerjaya anak-anak mereka pada masa hadapan. Di Malaysia, ramai ibu bapa yang berpendidikan memilih menggunakan bahasa Melayu atau bahasa Inggeris semasa bercakap dengan anak-anak mereka (Noor Aina et al., 2019: 9).

Bagi menjawab persoalan kajian, pilihan bahasa GI dalam domain khusus menunjukkan mereka lebih banyak menggunakan Bahasa Bajau Sama daripada bahasa Melayu. GII menunjukkan mereka lebih banyak menggunakan bahasa Melayu dalam domain khusus. Responden GIII turut menunjukkan mereka lebih banyak menggunakan bahasa Melayu dalam domain khusus. Sehubungan itu, Fishman (1991: 365) pernah mengatakan bahawa ketidakupayaan etnik minoriti untuk mengekalkan rumah atau keluarga sebagai domain utuh penggunaan bahasa ibunda adalah disebabkan fenomena perubahan bahasa. Dalam kes responden GII, mereka telah mengalami perubahan bahasa. Oleh itu, bahasa ibunda sudah tidak digunakan dalam domain rumah dan keluarga. Dalam domain kekeluargaan dan kejiranan terdapat pertuturan campur kod dan alih kod yang menunjukkan keakraban. Responden tidak menggunakan bahasa Bajau Sama sepanjang masa perbualan. Sebaliknya, mereka menggunakan campur kod dan alih kod mengikut konteks dan situasi yang sesuai.

\section{Kesimpulan}

Sebagai kesimpulan, GI dan GII masih memilih bahasa Bajau Sama dalam domain keluarga, namun GIII sudah beralih menggunakan bahasa Melayu. Pilihan dalam domain yang berhubungan dengan masyarakat, GI hanya memilih bahasa Bajau Sama dalam domain kejiranan tetapi GII dan GIII telah beralih memilih bahasa Melayu dalam semua domain yang dikaji. Kajian ini menyokong pendapat Fishman (1991) bahawa di bawah domain yang berlainan, terdapat satu variasi bahasa yang lebih dominan daripada variasi bahasa lain. Bahasa yang lebih dominan inilah yang memainkan peranan sebagai punca utama kemerosotan penggunaan bahasa ibunda sebagai bahasa di rumah. Penyelidik berpendapat perlu dijalankan kajian susulan tentang fenomena peralihan bahasa dalam kalangan tiga generasi penutur bahasa Bajau Sama di daerah Kota Belud pada masa hadapan. Walau bagaimanapun, penggunaan pilihan penggunaan bahasa dalam domain rumah menunjukkan corak komunikasi yang tidak tetap seperti yang ditemui dalam kajian Sarri (2016).

\section{Rujukan}

Banker, J. E. (1984). 'The West Coast Bajau Language”, in J.K King and S.A J.W King (eds), Language of Sabah: A survey report, 101-112. Canberra: Pacific Linguistics.

David, M. K. (2002). Methodological and Analytical Issues in Language Maintenance and Language Shift Studies. New York: Frankfurt am Main.

Evans, I. H. (1955). Notes on the Bajaus and other coastal tribes of North Borneo. Journal of the Malayan Branch of the Royal Asiatic Society, 25(1 (158), 48-55.

Fishman, J.A. (Eds.) (1968). Readings in the sociology of language, Vol. 2. The Hague: Mouton.

Fishman, J.A. (1971). "Domain and the relationship between micro and macrosociolinguistics". In John.J.Gumperz and Dell Hymes, eds. Direction in Sociolinguistics: The Ethnography of Commucation. New York : Holt, Rinehart \& Winston.

Fishman, J.A. (1972). Domains and the relationship between micro and macrosociolinguistics. In J. Gumperz \& D. Hymes (Eds.), Directions in sociolinguistics: The ethnography of communication (pp. 435-453). New York: Holt, Rinehart and Winston.

Fishman, J. A. (1991). Reversing Language Shift: Theoretical and Empirical Foundations of assistance to threatened languages. Clevedon, UK: Multilingual matters Ltd.

Holmes, J. (2001). An Introduction to Sociolinguistics. United Kongdom: Pearson Education Limited.

Hotma Simanjuntak. (2017). Pengekalan dan Peralihan Bahasa dalam Kalangan Orang Batak Toba di Pontianak, Indonesia. Tesis Ph.D, Universiti Malaya, Lembah Pantai, Malaysia. 
Ida Zulaeha. (2017). Strategi Pemertahanan Bahasa Daerah pada Ranah Pendidikan. Jurnal Peradaban Melayu. 12, 40-46.

Janse, M. (2003). Introductions: Language Death and Language Maintenance Problem and Prospects. In Janse, M., Sijmen, T., (Eds.), Language death and language Maintenance: Theoritical, practical and descriptive approaches (ix-xv). Amestrdam: John Benjamins Publishing.

Jeniri Amir. (2013). Bahasa Melayu Suara Dari Bawah. Kota Samarahan: Universiti Malaysia Sarawak.

Khairul Nizam Mohamed Zuki. (2017). Sikap dan Motivasi Murid Bajau dalam Mempelajari Bahasa Melayu sebagai Bahasa Kedua. Jurnal Pendidikan Bahasa Melayu. 7(1), 24-33.

Mohammed Azlan Mis. (2010). Lingua Franca Di Sarawak: Aplikasi Teori Pilihan Bahasa. GEMA Online ${ }^{\mathrm{TM}}$ Journal of Language Studies. 10(2), 97-116.

Noor Aina Dani \& Syeril Patrisia Kining. (2016). Impak Dialek Melayu Sabah ke atas Bahasa Ibunda Generasi Muda Etnik Kadazandusun. International Journal of the Malay World and Civilisation (IMAN). 4(2), 45-55:

Noor Aina Dani, Norazlina Mohd. Kiram, Mohd. Ariffin Mohd. Arif, Kamarlin Ombi, Roslan Suhailin, Sharil Nizam Sha'ri \& Daisy Paul. (2019). Endangered Intergenerational Language Transmission: Evidence from the Indigenous Dusun Society of Sabah, Malaysia. Pertanika Journal of Social Sciences \& Humanities. 27 (1), 1-12.

Omar, R., Alias, N., \& Seong, T. K. (2016). Pemilihan Bahasa Masyarakat Chetti Di Melaka. Jurnal Melayu. 15(2), 210-222.

Ravindranath, M. (2009). Language Shift and the Speech Community: Sociolinguistic Change in a Garifuna Community in Belize. Publicly Accessible Penn Dissertations. 33, 12-22.

Reduan Abang Amir. (2015). Ranah Bahasa Masyarakat Melayu Saribas di Sarawak. Tesis Ph.D, Universiti Putra Malaysia, Serdang, Malaysia.

Sa'adiah Ma'alip. (2014). Pemilihan Bahasa: Proses Peralihan Bahasa Masyarakat Orang Asli Che Wong. Jurnal Melayu. 12(1), 32-43.

Sarri, U. (2016). The linguistic impact of migration: the case of Albanian immigrant children in Greece. Ph.D thesis, Aston University, Birmingham, United Kingdom.

Saidatul Nornis Hj. Mahali (2012). Bajau Pantai Barat. Kuala Lumpur: Institute terjemahan dan buku Malaysia.

Sartini, N. W. (2015). Perilaku Bahasa Diaspora Orang Bali di JAwa Timur: Kajian Sosiolinguistik. KEMBARA: Jurnal Keilmuan Bahasa, Sastra, dan Pengajarannya. 1(1), 54-62.

Sather, C.A. (1974). Cultural affiliation in Eastern Sabah and Sulu Province. Borneo Research Bulletin. 6(1), 15-16.

Zuraini Seruji. (2014). Perubahan Sifat Leksikon Dialek Melayu Sarawak Mengikut Generasi Penutur. Tesis Ph.D, Universiti Putra Malaysia, Serdang, Malaysia. 